\title{
織物欠点検出機構とその基本的性能*1
}

$\begin{array}{lllll}\text { 台北工業専科学校 } & \text { 頼 } & \text { 鋕 平 } \\ \text { 渡辺测器株式会社 } & \text { 畧 迫 宗 能 } \\ \text { 東京工業大学 } & \text { 久 世 } & \text { 栄 一 }\end{array}$

\section{SIGNAL TRANSDUCER OF FABRIC DEFECTS AND ITS PERFORMANCES ${ }^{* 1}$}

\author{
By Lai Tsu-ping ${ }^{* 2}$, Muneyoshi Sezako ${ }^{* 3}$ and Eiichi Kuze*4 \\ -2 (National Taipei Institute of Technology, Shin-Sheng \\ South Road, Taipei, Taiwan, Republic of China) \\ *3 (Watanabe Instrument Co., Nishi-Shinagawa, \\ Shinagawa-ku, Tokyo, Japan) \\ *4 (Tokyo Institute of Technology, Ookayama, Meguro-ku, \\ Tokyo, Japan)
}

In scanning the surface of fabrics with a light spot, we can get the power of the reflection or transparency that periodically changes according to disposition, diameter or bend of the threads. Then, on application of a digital computer, a digital pattern of fabric is represented by a twodimentional array of points showing the reflection and transparency distributions of fabrics by a suitable scanning light spot.

On detecting the defects by the reflection or transparency from fabrics, it is necessary to design the size and shape of the scanning light spot at the fabrics in consideration of the some kinds of defects and the inherent noises being due to the normal fabric structures, also the frequency band determined by the resolving power and the scanning speed that are suitable to the electric amplifier system.

In general, the spaces between the threads in fabrics are much smaller than the thread diameters. When width of the scanning light spot is smaller than the thread diameter, we can detect the characters of the thread and thread interval in every each warp direction. When length of the scanning light spot is a little larger than the thread diameter, average characters of a few threads will be detected, eliminating the noises caused by the twists and fluffes of the threads. In our experiments, the width of the scanning light spot was set $0.2 \mathrm{~mm}$ and length $5 \mathrm{~mm}$ in consideration of practrical usefulness.

Moreover, the frequency band $f$ needed to design of the electro-optical amplifier is given by

$$
f=V / 2 b
$$

where $V$ is scanning speed of the light spot, $240 \times 10^{3} \mathrm{~mm} / \mathrm{sec}$, and $b$ is resolving power, $0.2 \mathrm{~mm}$.

Confirmation of the size and shape of the light spot, transient properties and frequency responses of the signal transduser was discussed with the some experimental equipments.

(Received January 9, 1982)

\footnotetext{
*1この報文を「自動娭反システムの試作研究(第1 報)， Studies on the Development of A New Automatic Fabric Defect Inspection System (Part 1)とする。
} 


\section{1. 緒䇾}

近年生産機械や検查機棫に上る自動化，省力化が進子， フィルム・板などの自動検查香寒用に供されるようにな ってきたが，織物についてはまだ目視検查に頼っている のか現状である。しかし目視検查では検查者の心理状態 や䌸労などで検査レべルが不安定になるので，機械的な 自動検査の実見が望まれている。

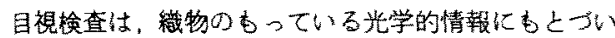
て行なかれることを考元れば，自動换查も同様の光学的 情報をつナログ的あるいはディジタル的比画像処理して 実行される妥当性のあること仕当然であるが，得られる 光学的情報には，反射上属折による幾何光学的情報之， 光波の干涉・回折，複㖤折なとによる波勳光学的情報上 加含まれる。

著者の 1 人はこのような観点から，これまで円形の光 点を一定速度で織物面に走查する光電走查法”）光心回 折 $^{32}$ ．ホログラフィ ${ }^{3)}$ などを応用し，織物構造上欠点構 造の特街を抽出主るための光情報処理について一連の基 磷的研究を行ない，その内容を発表してきた。るの結果， 系の配列之届曲構造でつくられる3次元構造を特徽とす る蟣物の光学的情報を抽出するには，適当な形状の光点 を繶物面上代走查しながら，これ机よって得ら扎る2次 元走查パターンを構成する連続的電经信号の变動を，定 量的飞観測する幾何光学的手法がもっとも適奵であると の結諭侄した。

今回てれらの基礎的研究結果にもとついて，織物次点 の信号正常な穖物構造自体の複雑な信号加ら分離して 格出し，证属接続される電子計算機への入力信号を大幅 に娍少させてデータ㚮理能力を向上した実用性の高い自 動检反装置を試作したので，その構成，性能などについ て一連の報告をすることとし，本報てはまず本装置に採 用した久点信号娭出システムの構成と性能について報告 する。

\section{2. 走查光点の形状設計と基礎実験}

織物の表面には正常な構造であってお，大は系の交錯 や系間隔方ら，小は系の撚りゃ毛羽に至るまでの，形態 上の多種多様の情報が含まれている。したがって反射上 透過て織物欠点情報老検出する婸合，走查光点の大きさ と形状住，次点信号之織物固有の系の撚りや毛羽で生ず る雜音信号之の比である $\mathrm{S} / \mathrm{N}$ 比，ならひ㐸点の大き

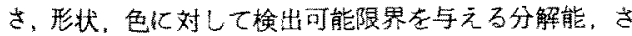
らには系配列と系の屈曲の周期性にもとづいて，走查速 度之分解能で決まる信号変化の周波数帯加光電变換增幅 系の設計に大きな影響を与えることなど、各分野の要因
を考感して最谪な内容をるつ上うに設副されねばならな い。

\section{1 形状陪計}

媺小な系の届曲や配列の不揃い，あるい恬れなどで 生ずるいくつ加の久点の光情報は，正常な織物の系の交 錯構造と系間隔にもとつく周期的光情報の，振偪と位相 の乱机の程度加ら模出できるもの上考元られる。したが って欠点の特徽を抽出するには，まず系の撚りと毛羽に 上る杂耗音情報奆取りのそいた周期的光情報のみを正確に 検出する必要がある。

別報”で報告したようにS/N比を無視して，微小な 欠点検出分解能のみ京如上うしして円形走査光点を織 物を構成する系の太さよりる小さくする上，反射之透過 で得られる光電变換検出信号は图 1 亿示すような，撚り と毛羽によって激しく装動する複雑な波形を含んで $\mathrm{S} / \mathrm{N}$ 比がすこかる悪くなるだけでなく，系軸に対する走査角

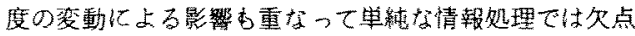
信号が㭘出できなくなるからである。

以上の観点加ら，たて系方向にこれと直交する上と乐 数本程度に跨がる長さの光点にすれば、1本1本の系に ある撚りや毛羽比上る微小な変動情報は，信号の平均化 によって除りるるのと考えた。しかし平均化の効果を高

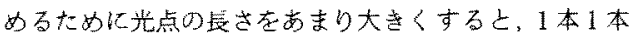
の系方向汇関連して生ずる版小な欠点情報屯消失するお それがあるので，長さの決定はたて・上と采の然りや毛 羽の多少上，次化前べる久点検出分解能を考慮して行な う必要がある。

一方どの位小さな次点まで桱出できるかの尺度が分解 能で，乙れは走查光点の幅で与元ら㧈る。系自体の欠点， 配列系間隔の不揃い系張力の不安定，貲物の付着混入， 污れなよ゙で生ずる織物の欠点の多くは1本1本のたて糸 方向江関連して生ずるという，織物の基本的な特性を考 歪すれば，光点の幅である分解能がたて系の直径よりあ 小さければ，各たて系方向にお讨る系ならびに系間隔の 特改を検出できるもの之考えた。

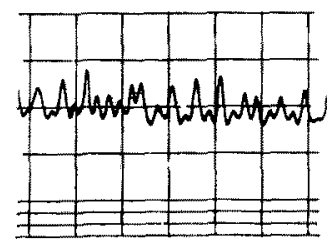

Fig. 1 Electro-optical detecting wave of a fabric by reflection of scanning round light spot smaller than thread diameter.

Scanning light spot diameter $=0.2$ thread diameter 
以上の考えから，良好な $\mathrm{S} / \mathrm{N}$ 比と高い 分解能を実現するには，走查光点の形状を 図2に示すように，たて系方向に長く，走 查方向であるよて系方向に微小な幅をむつ 長方形とし，長さ $a$ をよて系の太さまたは 系間隔 $y$ より，幅 $b$ をたて系の太さまたは 系間隔 $x$ 上り，次式

$$
\left.\begin{array}{l}
a=k_{1} y \\
b=x / k_{2}
\end{array}\right\}
$$

で決めればよいと考えた。ただし $k_{1}, k_{2}$ は走查光点の大きさを与える係数で, $k_{1}$ の 值は毛羽などによる雑音信号を除去するた めの平均化の効果, すなわ的 $\mathrm{S} / \mathrm{N}$ 比を考 慮して定まるので織物の種類との関係加ら， また $k_{2}$ の值は欠点検出の分解能加ら決ま るので久点の形状, 大きさならびにその種 類之の関係加ら，それぞれ実験的に求める ようにした。

さらに，走査光点の幅 $b$ は欠点の検出分 解能だけでなく，後述する走査速度 $V$ 上関 連して織物加らの周期的に変化する反射光と透過光の空 間周波数 $f$ を決定する。 $f$ の值は次式

$$
f=V / 2 b
$$

で与えられるが，てれは反射光之透過光を光電変換增幅 する受光部の周波数特性に影響を与え, 特性が悪いと折 角高い分解能で検出された欠点信号も受光部で消减する おそれも生ずる。したがって増幅系を含む受光部の空間 周波数特性屯考虑して $b$ の值を決定しなりればならない。

\section{2 基礴実駼}

(1) 式に示した走査光点の形状係数 $k_{1}, k_{2}$ を検討す るため，固定したいくつ加の織物表面に長方形光点を低 速度で走查する実験を行なった。試作システムの高速度 走榃による動特性については後述する。

光源には走查光点の広がりを極力さりるため，波長入 $=6328 \AA \AA \mathrm{A}$ の $-\mathrm{Ne}$ レーザを使用した。

図 3 は系表面が比較的滑らかで，たて系間およびよて

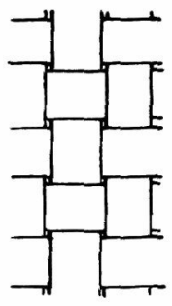

Construction of fabric

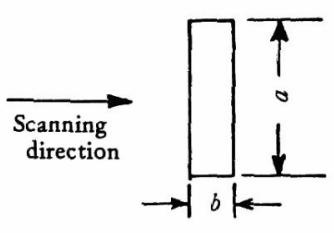

Shape of light spot
Fig. 2 Construction of fabric and shape of light spot.

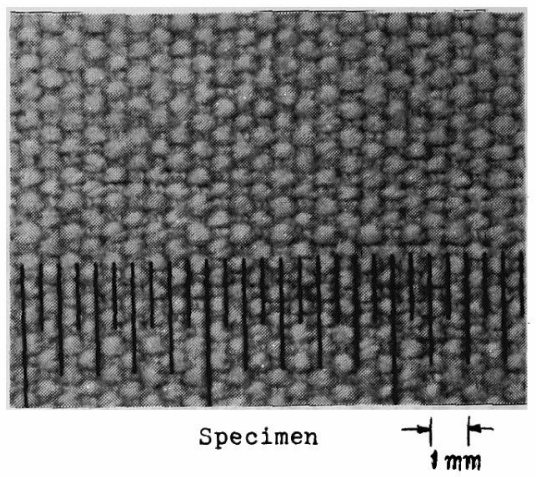

Fig. 3 Electro-optical detecting wave of a fabric defect by using of rectangular light spot.

系間の隙間の小さいフィラメント織物に対し，図2亿示 した走查光点の形状係数をそれぞれ $k_{1}=4, k_{2}=3$ とし てその反射光を光電変換する実験の結果で, 太いたて系 が 1 本入っている資料の場合である。図 1 のような系の 然りや毛羽にもとつくと考えられる激しい変動はなくな り，測定された系間隔の分布を示す図 4 から明らかなよ うに，たて系の間隔変動の分布を容易に求め得るととも に，系の太さの微小な変動を十分検出できることが理解 される。ただし図 4 の系間隔は基準を $100 \%$ として示し てある。しかしながらたて系間の隚間のきわめて小さい フィラメント織物の場合は, 図 5 に示すように糸抜けの ような大きな間隔の乱れは検出できるが，微小な凹凸に

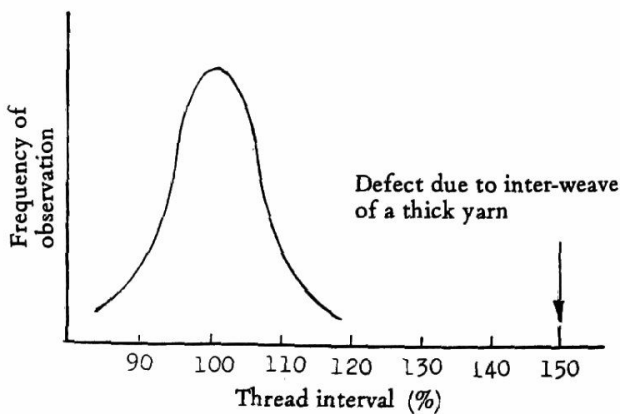

Fig. 4 Distribution of thread intervals in the specimen of Fig. 3.

The mean value of thread interval is $100 \%$. 

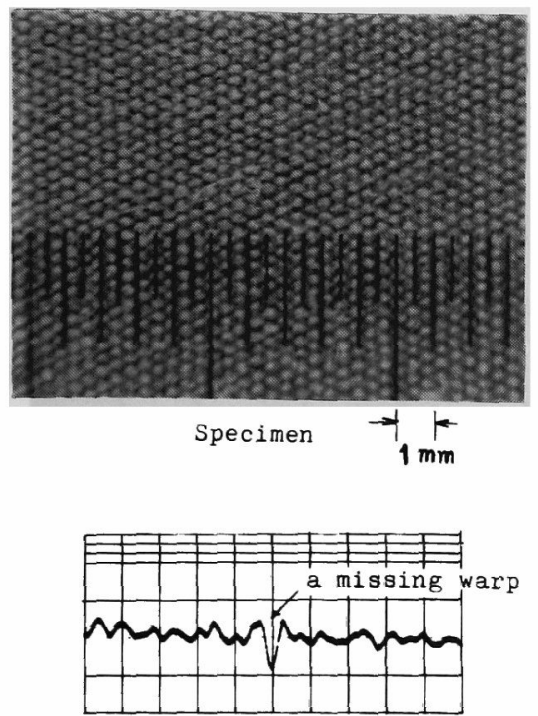

Fig. 5 Electro-optical detecting wave of fabric with a missing warp.

よるたて糸間隔の測定が困難で，てのような結果は毛羽 が系間隔の情報を埋没してしまうような，毛羽の多い織 物の場合にあしばしば見られた。これを解決するには， 情報の增幅を期待して走查光点の長さ $a$ をより大きくす るため, $k_{1}>6$ 亿すればたて糸間隔の情報が得られるよ
うになるととが確かめられた。しかしながらしみのよう な，1本 1 本の系にのっている微小な欠点情報は埋れて しまって検出ができなかった。

以上の観測結果から, 走査光点の $\mathrm{S} / \mathrm{N}$ 比を決める長 さ $a$ 上，分解能を支配する幅 $b$ の決定には，多くの種類 の織物の, 多くの欠点についての実験が必要であり，換 言すれば $a$ と $b$ との大きさで検出可能な欠点の範囲がお のずから決まるととが明らかになった。

\section{3. 試作検反システムの光学系}

困 6 は試作した織物欠点検出機構の光学系を示したも のである。

走查光点は固定した織物について行なう前述の上うな 多くの基礎実験加ら，代表的な織物の検反実績を考慮し て $a=5.0 \mathrm{~mm}, b=0.2 \mathrm{~mm}$ 之設定した。

また光点の走査速度 $V$ は， $30 \mathrm{~m} / \min の$ 織物送り速度 と $60 \mathrm{~cm}$ の走查幅を設定するとともに，毎回の走査で走 査面汇隚間ができないように，光点の長さ $a$ の $1 / 2$ ずつ をオーバーラップさせるようにし，かつ信号処理伝達時 間を考慮して，織物の幅方向に $V=240 \times 10^{9} \mathrm{~mm} / \mathrm{sec}$ とした。したがって 1 走査に要する時間は,

$600 \mathrm{~mm} /\left(240 \times 10^{3}\right) \mathrm{mm} / \mathrm{sec}=2.5 \mathrm{~ms}$ となる。

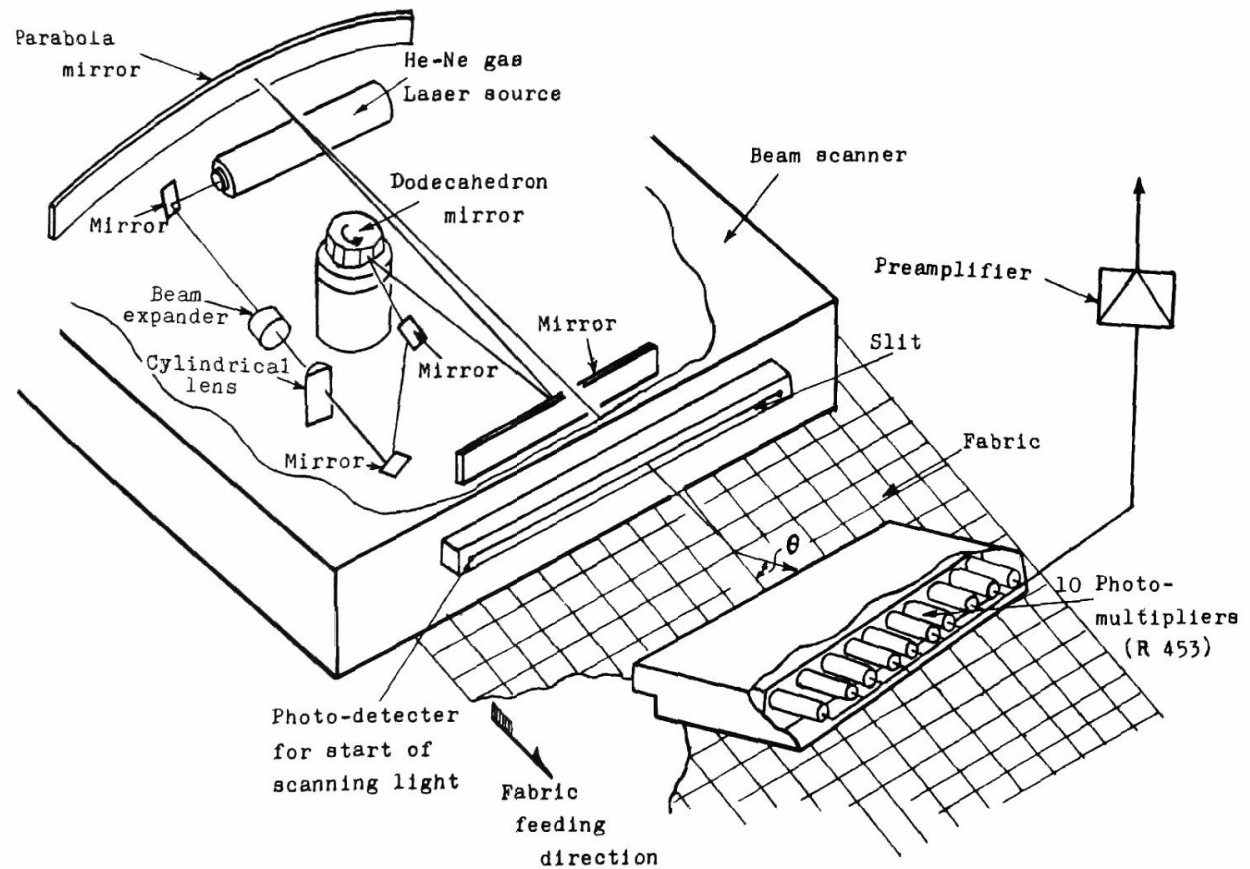

Fig. 6 Schematic drawing of optical equipment for fabric defect detecter. 


\section{1 走査光点の発生法と形状測定}

走查光点の形状のうち幅 $\boldsymbol{b}$ は走查方向の分解能を決め る要素として重要な数值である。したがってその発生を 跾密に実現するとともに，形状測定による検討がきわめ て重要な課題となる。

長方形の走査光点は，図6のレーザ装置加らの平行ビ 一ムをエキスパンダで所定の大きさの円形スポットにひ ろげたのち, 円柱レンズで幅方向に収束させてその焦点 面で光点幅 $b$ を $0.2 \mathrm{~mm}$ にするレンズ系，および光点の 長さ $a$ を $5 \mathrm{~mm}$ にするためのスリットによりつくられる。 被検査織物面は収束レンズの焦点面におかれるが, 前述 の走査速度 $V$ を奏琴するために 12 面体の回転ミラーを 使用しているため,てれからのビームの光学距離(光路 長)が織物面の各位置で一走查中変化する。この変化を 防いで常に一定強度の光点を織物面につくるために，放 物柱鏡加らの反射ビームを織物面に照射するようにした。

走査光点の長さ $a$ はかなり大きいので，その方向の光 の強度分布はほほ一様之考えられるとともに, 長さの観 測は容易であるが，レンズで収束されて実現される微小 な $0.2 \mathrm{~mm}$ の幅 $b$ の観測はかなり面倒である。すなわち 収束された微小な幅方向の光の強度は通常ガウス型の分 布をしていると考えられるからで, 図 7 に示す測定方法 で笠密な観测を行なった。

図 7 のラインセンサ (Line Sensor) は, 受光ピーク 間隔が $25 \mu$ 光電素子で構成されており，乙れに走查 を停止した光ビームを照射し，ラインセンサの各素子を 電気的に走查して目 8 亿示すような光強度分布のオシロ グラムを求め, その半值幅を測定した結果, $b=0.2 \mathrm{~mm}$ を満足していることが確認された。

\section{2 受光部の構成と性能}

図 6 に扔いて，織物加らの反射光之透過光を入力光之 して光電变換する受光部は，織物面に対してもっとも良 好な感度を実現する角度 $\theta$ で設置され，一たんスリガラ スで拡散された入力光をPMT (Photomultiplier Tube) 部之前置增幅器 (Preamplifier) とで変換增幅するよう に構成されている。

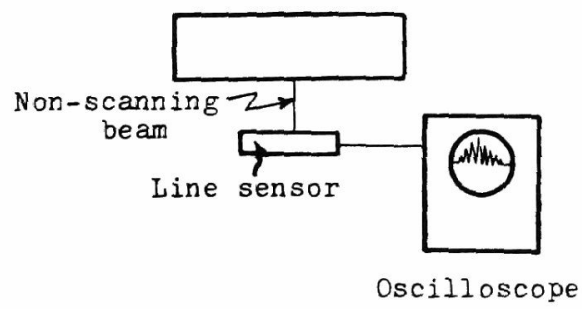

Fig. 7 Schematic drawing of light spot size measuring method.

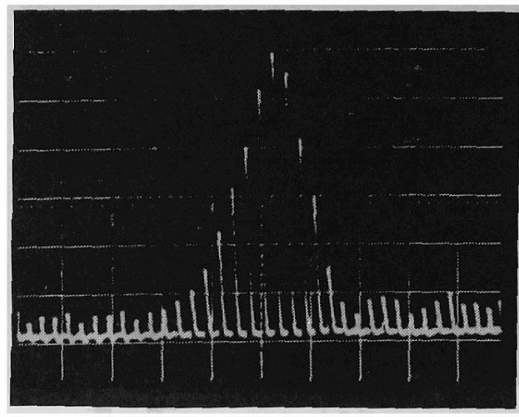

Fig. 8 Measuring result of light spot size. Each pulse interval is $25 \mu$. Pulses are detected by line sensor.

また一走査中の感度を一様にするための調整は, 走査 幅が広いと光をレンズ系を用いて 1 個のPMTに集める ような方法では困難なので，各々の感度が独立に調整可 能な 10 個のPMTを 1 列に並べるとともに，外光を遮 断するために受光部全体を暗箱で囲う構造にした。

受光部の性能は，一般に走査幅全体に対するPMT部 の感度の均一性之, 入力光の空間周波数に対する $\mathrm{PMT}$ 部之前置增幅器の応答特性で定まるもの之考えられる。

まず感度の均一性について実験的に考察してみた。欠 点のない織物加らの反射光および透過光を受光したとき の受光部の光電出力が図 9 Aのように均一であれば，そ のヒストグラムは図 $10 \mathrm{~A}^{\prime}$ のようにシャープになり，6 し欠点があれば異常レベルを示す受光入力のために例え ばA"のような山を示すはずである。しかし図9B，C のように不均一な光電出力の場合のヒストグラムは, 図 10 の $\mathrm{B}^{\prime} ， \mathrm{C}^{\prime}$ のように広がるため欠点検出感度が悪くな る。そこで織物を除去し，受光部に走查光点を直接照射 した場合よ，半透明プラスチック・フイルムであるマイ ラー紙に照射し，その反射光を受光した場合の，図 11 そ示す回路をもつ受光部のそれぞれの感度分布の測定結 果を図 12 に示す。10 個のPMTの感度特性がほぼ均一

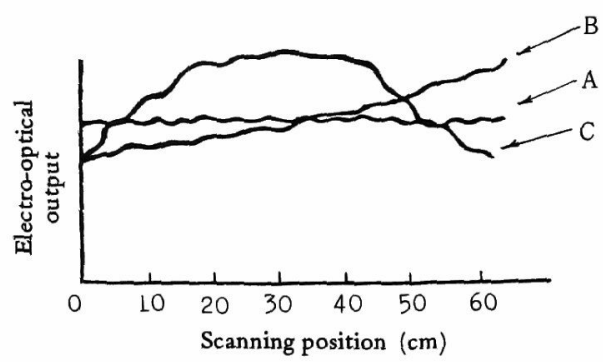

Fig. 9 Explanatory drawing of electro-optical detecting output.

$A$ is uniform and $B, C$ are not uniform electro-optical output. 


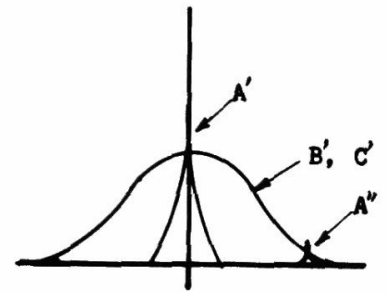

Fig. 10 Histogram of output showing in Fig. 9. $A^{\prime}, B^{\prime}$, and $C^{\prime}$ are histograms corresponding with A, B, and C in Fig. 9, respectively, and $A^{\prime \prime}$ is histogram corresponding with fabric defects.

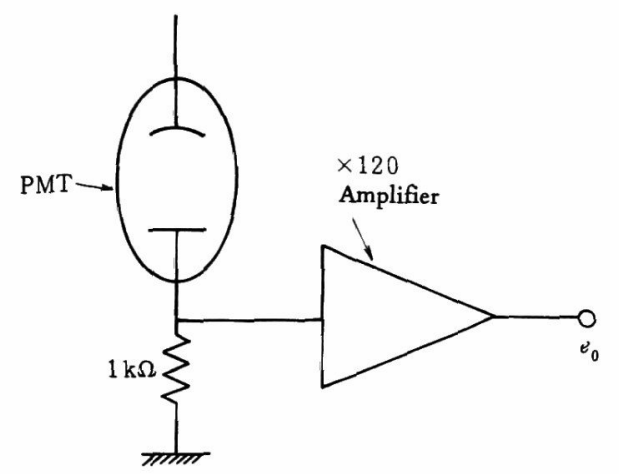

Fig. 11 Electro-optical circuit of detecting part.

であるとともに，マイラー紙による反射光感度分布が士 5\%以内に収まっており，かなり良い結果が得られた。 なおヒストグラム作成法とそれによる欠点の識別手法に ついては，次報で詳細報告する。

またどの位小さな欠点まで検出できるかは，走査光点 の形状寸法のほかに，パルス状または周期的に変化する
入力光を, 図11亿示す回路の PMT部々前置增幅器より 構成される受光部が，アナログ信号 2 次変換する際の過 渡特性と周波数特性によっても支配されることは、前述 した通りである。

図13(a) は種々の大きさと形状の欠点を想定して作 ったテストパターンで, 半透明フィルム亿 6 種類の幅の 長方形黒線を綐横に交互に配列してマークしてある。こ のテストパターンの横方向に，前述したように幅が 0.2 $\mathrm{mm}$, 長さが $5 \mathrm{~mm}$ の長方形光点を走查速度 $240 \times 10^{3}$ $\mathrm{mm} / \mathrm{sec}$ で1 回走査し, 受光部出力として得られたのか 同図(b)に示すオシログラムで，乙れによって受光部の 過渡応答を知ることができる。透過光，反射光とも受光 部の光電出力を, 極性を反転してオシログラフに入力し てあるので，各オシログラムの鋭いピークが走查光点と

$$
|-|-|-|-\mid-
$$

(a)

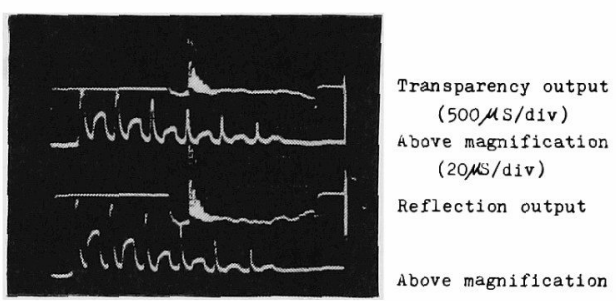

(b)

Fig. 13 Transient response of electro-optical detecting part.

(a) test pattern, (b) oscillogram

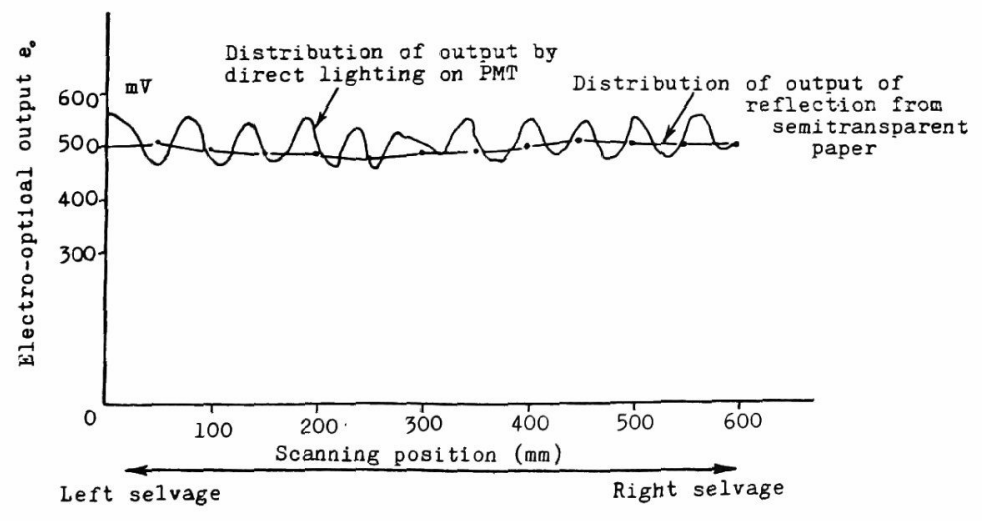

Fig. 12 Measuring result of sensitivity distribution for 10 PMTs. Scanning range $=600 \mathrm{~mm}$ 
綎方向の黑線とが一政したととろで あり，横長の黑楾との重なりのとと ろでは，光点のかなりの部分が黒鉛 加ら外れるので低い山形の曲線上な る。どの応答曲線にもある程度のお くれが見られるが，本研究の目的で ある久点検出には十分な特性をすつ ことが理解される。また反射による動 的光電出力を，図14（a)に示すよう なマイラー紙にマーク・スペース $t$ を1：1にしたテストパターンで観 測した結果を同四(b)に示す。マー 湢 $t$ か $1 \mathrm{~mm}$ 以下では $t$ の隇少と と纪出力が低下するが，対象とす 万久点の大きさに対して十分な出力 が得られるものと考えた。

一方試作装置では走查光点の分解能を $0.2 \mathrm{~mm}$ ，走查 速度を $240 \times 10^{8} \mathrm{~mm} / \mathrm{sec}$ 亿設定したので（2）式より 検出可能な最大周波数は $600 \mathrm{kHz}$ となる。図 15 は前置 増偪器の周波数特性老求めるため图示の回路で実験した 結果であるが、ほほ $1 \mathrm{MHz}$ までのゲインが一定であり， $600 \mathrm{kHz}$ の信号增幅の要求が十分力バーされるととが確 認された。

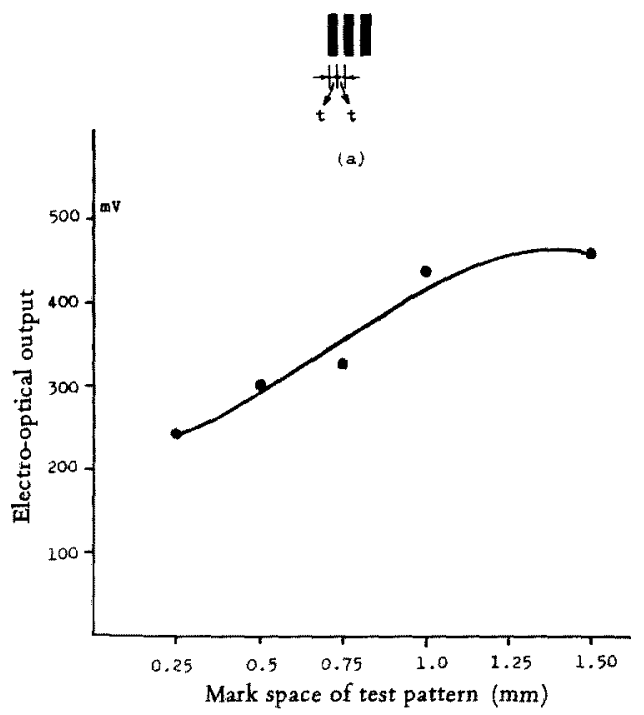

Fig. 14 Response characteristics of electro-optical detecting part.

Scanning time per unit length $(2.5 \mathrm{~ms} / 600 \mathrm{~mm}=4 \mu \mathrm{s} / \mathrm{mm})$

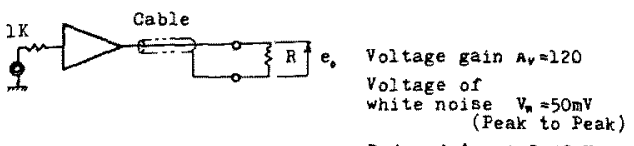

Reduced input $=0.42 \mathrm{mV}$

Output inpedance of reamplifier

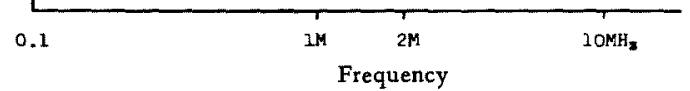

Fig. 15 Gain characteristics of preamplifier.

今回は試作した自動㭘反システムの，織物欠点検出機 構の構成とその基本的な各種﨡能についての研究結果を 報告した。その要点をまとめれば次のようになる。

(1) 従来の研究で開発された光学装置では，目視可能 な織物の久点でも光学的情報として取りだせないいいつ かのあのがあり、とれらを詳緗に検討した結果, 走查光

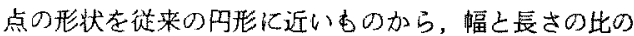
犬きい長方形の6のに設計する必要性を見いだし，その 効果を詳細に検討した。その結果織物の欠点に無開係で 加つその検出を妨害すると考えられる，糸の撚りや毛羽 による情報を除去し，糸の铅小な届曲や間隔の不揃いや 污扎によ重要な欠点の多くを検出できることを確認し た。

（2）走查光点の北状が欠点検出の分解能を支配するの で，試作システムにおける走查光点の発生方法々形状检 定を産重かつ慎重に行なった。

（3）試作システムの光点の走查速度がきわ好大きい ので，受光部で得られる2次変換信号の過渡特性之周波 数特性を，特別に設計したテストパターンで慎重に検討 した結果，良好な性能をもつととが確認された。

本研究は昭和 51 年度より 3 年間にわたって中小企業 振與事業団が行なった技術開発事業に関連して行なった 基碳研究であって，昭和 56 年米国 North Carolina必 Raleighで行なわれた1981 Annual Textile Industries Conference Cosponsored by the ASME Textile Industries Division and the Society of Fiber Science and Technology, Japanで発表した。な招究 に拹力された東京工業大学名举教授，霜屋潔先生，渡边 
测器株式会社会長，渡辺健二氏に深く感謝する。

\section{文献}

1) 古田好治，久世栄一、䋐学誌，29， $\Upsilon-224$ (1973)

久世栄一, 西出照雄, 織学誌, $32, T-178$
(1976)

2) 秋山隆一, 久世栄一。織学誌, $33, T-439$ (1977)

3）秋山隆一，久世策一，䋐学誌，35， T-202 (1979) 